\title{
Endometrial Mixed Cell Adenocarcinoma
}

National Cancer Institute

\section{Source}

National Cancer Institute. Endometrial Mixed Cell Adenocarcinoma. NCI Thesaurus. Code C40153.

An adenocarcinoma that arises from the endometrium and is characterized by the presence of both type I and type II endometrial adenocarcinoma components. The minor component constitutes at least $5 \%$ of the entire tumor. 